\title{
Development of Plain cement Mortar mixed with Tamrind Kernel Powder
}

\author{
S. Venkatraman, K. Kiruthiga, B.Kaviya
}

\begin{abstract}
Mortar is a significant glue used to tie building squares, for example, stones, squares, and solid square work units together, fill and seal the sporadic holes among them, and from time to time join flawless shades or models in workmanship dividers. In its broadest sense mortar wires pitch, dull top, and delicate mud or soil, for example, utilized between mud blocks The sort and degree of the fix mortar is coordinated by a mortar examination. There are a couple of sorts of bond mortars and included substance. The tamarind tree produces unit like common item, which contain a consumable crush that is used in cooking styles the world over. Various livelihoods of the crush join standard medicine and metal clean. The wood can be used for carpentry, and tamarind seed oil can be isolated from the seeds. Because of the tamarind's various uses, advancement has spread far and wide in tropical and subtropical zones. The magnificent gelling cum bond properties of the decorticated seed powder can incite a couple of uses in sustenance and pharmaceutical ventures which are evident by the amount of research papers similarly as patent applications. This article thusly bases on the possible results of using the seed in a couple of sustenance and non-sustenance endeavors with explicit reference to physical and structuring properties, hydration direct, rheological properties, valuable and healthy qualities, and the planning of the tamarind seed for progressively broad applications.
\end{abstract}

Keywords : Cement mortar, Tamarind Kernel powder, Hydrocolloids, Additive

\section{INTRODUCTION}

The most outstanding clasp since the mid twentieth century is Portland concrete anyway the old folio lime mortar is so far usefor every one of the Trials I to VI, the solid shape examples in some new improvement. Lime and gypsum as mortar of Parisvere casted, restored and tried to decide the compressive are used particularly in the fix and re pointing of structures an\&uality at the age of 7, 14 and 28 days structures since it is huge the fix materials resemble the main materials. [8],[ 10], [12] Tamarind seed is an underutilized side-effect of the tamarind mash industry. Just a little bit of the seed, as tamarind part powder (TKP), is utilized as a measuring The Cement Mortar was poured in the shape and pressed material in the material, paper, and jute businesses. Despite theittingly so as to not have any voids. Following 24 hours these fact that numerous utilizations of this seed are conceivable, theremodels were ousted from the molds and the test models were have been not really some other uses for it including utilizing it a put in water for reestablishing. The top surface of these an added substance in sustenance details. [2 ],[ 4],[6]The

Revised Manuscript Received on July 22, 2019.

S.Venkatraman, Deparment of Civil Engineering, Bharath Institute of Higher Education and Research, Tamilnadu,India. Email:mailmagik@yahoo.com

K.Kiruthiga, Deparment of Civil Engineering, Bharath Institute of Higher Education and Research, Tamilnadu,India. Email: kiruthiga1992@gmail.com

B.Kaviya, Deparment of CivilEngineering, Bharath Institute of Higher Education and Research, Tamilnadu,India. Email: santhokavi.18@gmail.com astounding gelling cum cement qualities of the decorticated seed powder can prompt a few applications in nourishment and pharmaceutical ventures which are obvious by the quantity of research papers just as patent applications. [19],[21],[23

\section{TEST PROCEDURE}

\section{A. Workability Test On Fresh Pc Mortar}

Droop test was used to choose the helpfulness of fresh PC Mortar. Hang test was finished by Seems to be: 1199 1959. The gadget used for doing hang test were hang cone and pressing bar. Within surface of the structure was totally cleaned and associated with a light layer of oil. The structure was determined to a smooth, level, unyielding and non-porous surface. The structure was then filled in four layers with normally mixed mortar, each generally to one-fourth of the stature of the shape. Each layer was stuffed on various occasions by the balanced completion of the pressing bar (strokes are scattered similarly over the cross region). After the top layer was rodded, the mortar was hit off the level with a trowel The refinement in level between the height of the structure and that of the most amazing motivation behind the subsided mortar was evaluated. This refinement in height in $\mathrm{mm}$ was taken as the hang of the mortar. [25],[27],[29]

\section{B. Tests On Hardened Cement Mortar}

\section{Compressive Strength Test on Cubes} models was made even and smooth. This was done by putting solid paste and spreading effectively on whole area of model. These models were attempted by Universal Testing Machine following 7 days, 14 days and 28 days diminishing. Weight was associated a tiny bit at a time at the rate of $140 \mathrm{~kg} / \mathrm{cm} 2$ each minute till the models failed. For all of the primers I to VI, the square models were reestablished properly and attempted to choose the compressive quality at the age of 7 , 14 and 28 days and the specific results are given in Table 4.5. [26],[28],[30] 


\section{COMPRESSIVE STRENGTH OF CEMENT MORTAR CUBES AT 7, 14 AND 28 DAYS}

\begin{tabular}{|c|c|c|c|}
\hline \multirow{7}{*}{ Trials } & $\begin{array}{c}\text { Percentage } \\
\text { of } \\
\text { Tamarind } \\
\text { Kernel } \\
\text { Powder } \\
\text { added }\end{array}$ & $\begin{array}{c}\text { Curing } \\
\text { period in } \\
\text { days }\end{array}$ & $\begin{array}{c}\text { Mean } \\
\text { compressive } \\
\text { strength of } \\
\text { Cube } \\
\text { specimens in } \\
\text { N/mm }\end{array}$ \\
\hline \multirow{3}{*}{ I. } & $0 \%$ & 7 & 6.43 \\
\cline { 2 - 4 } & $0 \%$ & 14 & 6.94 \\
\cline { 2 - 4 } & $0 \%$ & 28 & 10.94 \\
\hline
\end{tabular}

\begin{tabular}{|c|c|c|c|}
\hline Trials & $\begin{array}{c}\text { Percentage of } \\
\text { Tamarind } \\
\text { Kernel } \\
\text { Powder } \\
\text { added }\end{array}$ & $\begin{array}{c}\text { Curing } \\
\text { period in } \\
\text { days }\end{array}$ & $\begin{array}{c}\text { Mean } \\
\text { compressive } \\
\text { strength of } \\
\text { Cube } \\
\text { specimens in } \\
\text { N/mm }\end{array}$ \\
\hline \multirow{3}{*}{ II. } & $0.5 \%$ & 7 & 6.97 \\
\cline { 2 - 4 } & $0.5 \%$ & 14 & 7.32 \\
\cline { 2 - 4 } & $0.5 \%$ & 28 & 11.85 \\
\hline
\end{tabular}

\begin{tabular}{|c|c|c|c|}
\hline \multirow{7}{*}{ Trials } & $\begin{array}{c}\text { Percentage } \\
\text { of } \\
\text { Tamarind } \\
\text { Kernel } \\
\text { Powder } \\
\text { added }\end{array}$ & $\begin{array}{c}\text { Curing } \\
\text { period in } \\
\text { days }\end{array}$ & $\begin{array}{c}\text { Mean } \\
\text { compressive } \\
\text { strength of } \\
\text { Cube } \\
\text { specimens in } \\
\text { N/mm }\end{array}$ \\
\hline \multirow{3}{*}{ III. } & $0.75 \%$ & 7 & 8.52 \\
\cline { 2 - 4 } & $0.75 \%$ & 14 & 9.07 \\
\cline { 2 - 4 } & $0.75 \%$ & 28 & 12.95 \\
\hline
\end{tabular}

\begin{tabular}{|c|c|c|c|}
\hline \multirow{2}{*}{ Trials } & $\begin{array}{c}\text { Percentage of } \\
\text { Tamarind } \\
\text { Kernel } \\
\text { Powder } \\
\text { added }\end{array}$ & $\begin{array}{c}\text { Curing } \\
\text { period in } \\
\text { days }\end{array}$ & $\begin{array}{c}\text { Mean } \\
\text { compressive } \\
\text { strength of } \\
\text { Cube } \\
\text { specimens in } \\
\text { N/mm }\end{array}$ \\
\hline \multirow{3}{*}{ IV. } & $1 \%$ & 7 & 9.06 \\
\cline { 2 - 4 } & $1 \%$ & 14 & 9.97 \\
\cline { 2 - 4 } & $1 \%$ & 28 & 13.59 \\
\hline
\end{tabular}

\begin{tabular}{|c|c|c|c|}
\hline \multirow{7}{*}{ Trials } & $\begin{array}{c}\text { Percentage } \\
\text { of } \\
\text { Tamarind } \\
\text { Kernel } \\
\text { Powder } \\
\text { added }\end{array}$ & $\begin{array}{c}\text { Curing } \\
\text { period in } \\
\text { days }\end{array}$ & $\begin{array}{c}\text { Mean } \\
\text { compressive } \\
\text { strength of } \\
\text { Cube } \\
\text { specimens in } \\
\mathbf{N} / \mathbf{m m}^{2}\end{array}$ \\
\hline \multirow{3}{*}{ V. } & $1.5 \%$ & 7 & 10.97 \\
\cline { 2 - 4 } & $1.5 \%$ & 14 & 13.07 \\
\cline { 2 - 4 } & $1.5 \%$ & 28 & 15.34 \\
\hline
\end{tabular}

\begin{tabular}{|c|c|c|c|}
\hline \multirow{7}{*}{ Trials } & $\begin{array}{c}\text { Percentage } \\
\text { of } \\
\text { Tamarind } \\
\text { Kernel } \\
\text { Powder } \\
\text { added }\end{array}$ & $\begin{array}{c}\text { Curing } \\
\text { period in } \\
\text { days }\end{array}$ & $\begin{array}{c}\text { Mean } \\
\text { compressive } \\
\text { strength of } \\
\text { Cube } \\
\text { specimens in } \\
\text { N/mm }\end{array}$ \\
\hline \multirow{3}{*}{ VI. } & $2 \%$ & 7 & 9.98 \\
\cline { 2 - 4 } & $2 \%$ & 14 & 10.80 \\
\cline { 2 - 4 } & $2 \%$ & 28 & 13.86 \\
\hline
\end{tabular}

\section{CONCLUSION}

In this project, an experimental study has been conducted to addition of Tamarind Kernel Powder at $0 \%, 0.5 \%$, $0.75 \%, 1 \%, 1.5 \%$ and $2 \%$ respectively to study the increase in the strength of Cement Mortar. The compressive strength was found to increase at $1.5 \%$ addition of Tamarind Kernel Powder to the Cement Mortar, when compared with 0\% Cement Mortar. The compressive strength was found to gradually decrease at $2 \%$ addition of Tamarind Kernel Powder to the Cement Mortar. Therefore, we conclude that the addition of Tamarind Kernel Powder to the Cement Mortar shall be up to $1.5 \%$ in Cement Mortar and not more than that is suitable for construction works. Moreover, it reduces the construction cost as cement content is reduced and it also reduces the environmental pollution. Hence, using Tamarind Kernel Powder as addition to the Cement Mortar is concluded to be advantageous and beneficial to the construction industry. [8],[ 10],[12]

\section{REFERENCES}

1. Iyappan L., Dayakar P., Identification of landslide prone zone for coonoortalukusing spatial technology, International Journal of Applied Engineering Research,V-9,I-22,PP-5724-5732,Y-2014.

2. Kumar J., Sathish Kumar K., Dayakar P.,Effect of microsilica on high strength concrete, International Journal of Applied Engineering Research,V-9,I-22,PP-5427-5432,Y-2014.

3. Dayakar P., Vijay Ruthrapathi G., Prakesh J., Management of bio-medical waste, International Journal of Applied Engineering Research,V-9,I-22,PP-5518-5526,Y-2014.

4. Swaminathan N., Dayakar P., Resource optimization in construction project, International Journal of Applied Engineering Research,V-9,I-22,PP-5546-5551,Y-2014.

5. Venkat Raman K., Dayakar P., Raju K.V.B.,An experimental study on effect of cone diameters in penetration test on sandy soil, International Journal of Civil Engineering and Technology,V-8,I-8,PP-1581-1588,Y-2017.

6. Saritha B., Chockalingam M.P.,Photodradation of malachite green DYE using TIO2/activated carbon composite,International Journal of Civil Engineering and Technology,V-8,I-8,PP-156-163,Y-2017

7. Shendge R.B., Chockalingam M.P., Saritha B., Ambica A.,Swat modelling for sediment yield: A case study of Ujjani reservoir in Maharashtra, India,International Journal of Civil Engineering and Technology, V-9,I-1,PP-245-252,Y-2018

8. Chockalingam M.P., Balamurgan V.,Modernisation of an existing urban road-sector in Chennai, a case study report,International Journal of Civil Engineering and Technology,V-8,I-8,PP-1457-1467,Y-2017

9. Saritha B., Chockalingam M.P.,Adsorption study on removal of basic dye by modified coconut shell adsorbent, International Journal of Civil Engineering and Technology,V-8,I-8,PP-1370-1374,Y-2017

10. Saritha B., Chockalingam M.P.,Adsorptive removal of heavy metal chromium from aqueous medium using modified natural adsorbent,International Journal of Civil Engineering and Technology,V-8,I-8,PP-1382-1387,Y-2017

11. Chockalingam M.P., Palanivelraja S.,Retrospective analysis of theoretical model used for forecasting future air quality near the north Chennai thermal power plant,International Journal of Civil Engineering and Technology,V-8,I-8,PP-1457-1467,Y-2017

12. Saritha B., Chockalingam M.P.,Photodegradation of methylene blue dye in aqueous medium by $\mathrm{Fe}-\mathrm{AC} / \mathrm{TiO} 2$ Composite,Nature Environment and Pollution Technology,V-17,I-4,PP-1259-1265,Y-2018

13. Shendge R.B., Chockalingam M.P., Kaviya B., Ambica A.,Estimates of potential evapotranspiration rates by three methods in upper Bhima Basin, In Maharashtra, India,International Journal of Civil Engineering and Technology,V-9,I-2,PP-475-480,Y-2018

14. Shendge R.B., Chockalingam M.P.,The soil and water assessment tool for Ujjani Reservoir,International Journal of Mechanical Engineering and Technology,V-9,I-2,PP-354-359,Y-2 
15. Shendge R.B., Chockalingam M.P.,A review on soil and water assessment tool,International Journal of Mechanical Engineering and Technology,V-9,I-2,PP-347-353,Y-2018

16. Sachithanandam P., Meikandaan T.P., Srividya T.,Steel framed multi storey residential building analysis and design,International Journal of Applied Engineering Research,V-9,I-22,PP-5527-5529,Y-2014

17. Meikandaan T.P., Ramachandra Murthy A.,Study of damaged RC beams repaired by bonding of CFRP laminates, International Journal of Civil Engineering and Technology,V-8,I-2,PP-470-486,Y-2017

18. Meikandaan T.P., Ramachandra Murthy A.,Retrofittng of reinforced concrete beams using GFRP overlays,International Journal of Civil Engineering and Technology,V-8,I-2,PP-423-439,Y-2017

19. Meikandaan T.P., Ramachandra Murthy A.,Flexural behaviour of RC beam wrapped with GFRP sheets,International Journal of Civil Engineering and Technology,V-8,I-2,PP-452-469,Y-2017

20. Meikandaan T.P., Murthy A.R.,Experimental study on strengthening of rc beams using glass Fiber,International Journal of Civil Engineering and Technology,V-9,I-11,PP-959-965,Y-2018

21. Meikandaan T.P., Hemapriya M.,Use of glass FRP sheets as external flexural reinforcement in RCC Beam,International Journal of Civil Engineering and Technology,V-8,I-8,PP-1485-1501,Y-2017

22. Saraswathy R., Saritha B.,Planning of integrated satellite township at Thirumazhisai,International Journal of Applied Engineering Research,V-9,I-22,PP-5558-5560,Y-2014

23. Saritha B., Ilayaraja K., Eqyaabal Z.,Geo textiles and geo synthetics for soil reinforcement,International Journal of Applied Engineering Research,V-9,I-22,PP-5533-5536,Y-2014

24. Ambica A., Saritha B., Changring G., Singh N B., Rajen M., Salman Md.,Analysis of groundwater quality in and around Tambaram taluk, Kancheepuram district,International Journal of Civil Engineering and Technology,V-8,I-8,PP-1362-1369,Y-2017

25. Arunya A., Sarayu K., Ramachandra Murthy A., Iyer N.R.,Enhancement of durability properties of bioconcrete incorporated with nano silica,International Journal of Civil Engineering and Technology,V-8,I-8,PP-1388-1394,Y-2017

26. Ilayaraja K., Krishnamurthy R.R., Jayaprakash M., Velmurugan P.M., Muthuraj S.,Characterization of the 26 December 2004 tsunami deposits in Andaman Islands (Bay of Bengal, India),Environmental Earth Sciences,V-66,I-8,PP-2459-2476,Y-2012

27. Ilayaraja K.,Morphometric parameters of micro watershed in Paravanar sub-basin, Cuddalore District,International Journal of Civil Engineering and Technology,V-8,I-8,PP-1444-1449,Y-2017

28. Ilayaraja K., Singh R.K., Rana N., Chauhan R., Sutradhar N.,Site suitability assessment for residential areas in south Chennai region using remote sensing and GIS techniques,International Journal of Civil Engineering and Technology,V-8,I-8,PP-1468-1475,Y-2017

29. Ilayaraja K., Reza W., Kumar V., Paul S., Chowdhary R.,Estimation of land surface temperature of Chennai metropolitan area using Landsat images,International Journal of Civil Engineering and Technology,V-8,I-8,PP-1450-1456,Y-2017

30. Chitra R.,Experimental study on beam using steel fiber and latex,International Journal of Civil Engineering and Technology,V-8,I-8,PP-1395-1403,Y-2017

31. Chitra R.,Analysis of traffic and management at Kovilambakkam intersection,International Journal of Civil Engineering and Technology, V-8,I-8,PP-1433-1443,Y-2017

32. Aswathy M.,Experimental study on light weight foamed concrete,International Journal of Civil Engineering and Technology,V-8,I-8,PP-1404-1412,Y-2017

33. Aswathy M.,Wastewater treatment using constructed wetland with water lettuce (Eichornia Crasipies),International Journal of Civil Engineering and Technology,V-8,I-8,PP-1413-1421,Y-2017

34. Kiruthiga K., Anandh K.S., Gunasekaran K, Assessment of influencing factors on improving effectiveness and productivity of construction engineers, 2015, International Journal of Applied Engineering Research, V - 10,I -17,p -13849-13854

\section{AUTHORS PROFILE}

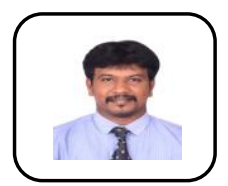

S.Venkatraman Assistant Professor, Department of Civil Engineering, Bharath Institute of Higher Education and Research, Chennai, India

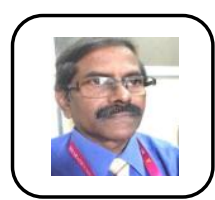

K.Kiruthiga Assistant Professor, Department of Civil Engineering, Bharath Institute of Higher Education and Research, Chennai, India

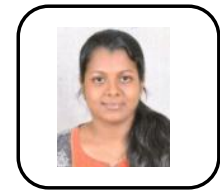

B.Kaviya Assistant Professor, Department of Civil Engineering, Bharath Institute of Higher Education and Research, Chennai, India 